\title{
QUARTERLY ANALYSIS: \\ The Progress of Monetary, Banking and Payment System Quarter IV - 2012
}

\author{
Author Team of Quarterly Report, Bank Indonesia
}

Indonesia's economic growth in the fourth quarter 2012 was still going strong, although it was slower than the previous quarter. Indonesia's economic growth in the fourth quarter of 2012 reached $6.11 \%$, while for the whole of 2012 it reached $6.23 \%$. Good economic growth was supported by quite strong domestic demand. Consumption and investment performance still grew strong during this quarter, though it was moderate compared with the previous period. Export performance began to show improvement in line with the economic recovery in some major trading partner countries. Imports recorded a high growth along with the strong domestic demand. Looking ahead, for the whole of 2013, economic growth is expected to reach the range of $6.3 \%-6.8 \%$.

The Indonesia's balance of payments (BOP) in the fourth quarter of 2012 improved. This is reflected in the surplus of 3.2 billion U.S. dollars during the quarter, which was higher than the previous one. Improved performance was driven by an increase in the surplus balance of payments in the Capital and Financial Transaction (CFT) that was greater than the increase in the Current Account deficit (CA). The surplus in CFT balance was supported by the sustained investor confidence, and by additional liquidity in the global financial markets resulting from monetary expansion in developed countries. Conversely, the current account had a deficit due to the slow global economic recovery amid robust domestic demand. Throughout the year of 2012, the balance of payments recorded a surplus of 0.2 billion U.S. dollars. As a result, the amount of reserves at the end of December 2012 stood at 112.8 billion U.S. dollars, equivalent to 6.1 months of imports and government's foreign debt payments.

During the year 2012, the exchange rate depreciated, yet despite this, its volatility was maintained at a relatively low level. On average, the rupiah depreciated by $6.3 \%$ (yoy) to Rp9.358 per dollar from Rp8.768 per U.S. dollar in the previous year. Meanwhile, point-to-point, the rupiah depreciated by $5.91 \%$, and closed at Rp9.638 per U.S. dollar with a volatility maintained at the level of $4.3 \%$ (annualized). Controlled rupiah volatility is closely linked to Bank Indonesia's policy in stabilizing the rupiah exchange rate at low levels of volatility.

Inflation remained under control during the year 2012 at a low level with the inflation target in the range of $4.5 \%+1 \%$. Controlled inflation is a result of Bank Indonesia policies, supported by improving policy coordination with the Government. Inflation in 2012 was recorded 
at $4.3 \%$ (yoy) mainly driven by stable core inflation, controlled volatility of food inflation, and low inflation administered prices. Core inflation was stable, supported by the implementation of a monetary strategy and macro-prudential policy mix to control inflationary pressures from the demand side, the price of imported commodities, and inflation expectations. In addition, subdued inflation was also supported by the more intensive coordination between Bank Indonesia and the Government through the forums of Inflation Control Team at national and regional level (TPI and TPID), especially in efforts to increase production, coordination, distribution, and food price stabilization strategies.

Stability of the financial system and banking intermediation function were properly maintained. Solid industry performance was reflected in the high Capital Adequacy Ratio (CAR), which was well above the minimum 8 percent, and the maintenance of the ratio of NonPerforming Loans (NPL) gross under 5\%. Meanwhile, credit growth by the end of December 2012 reached $23.1 \%$ (yoy), up from $22.3 \%$ (yoy) in the previous month. Working capital loans grew quite substantially by $23.2 \%$ (yoy), and investment credit growth was stable at a high level of $27.4 \%$ (yoy), which is expected to increase the capacity of the national economy. At the same time, consumer credit grew by $20.0 \%$ (yoy). Going forward, Bank Indonesia believes the stability of the financial system will remain intact with banking intermediation that will increase along with an increase in performance of the national economy.

Solid economic performance in Indonesia cannot be separated from the support of a reliable payment system. In economic activities, the strategic role of payment systems is to ensure the implementation of various payment transactions of economic activity and other activities undertaken by both the public and private sectors. During the fourth quarter of 2012, the payment system demonstrated positive performance. This was supported by Bank Indonesia's policy to ensure the implementation of an efficient, fast, secure, and reliable payment system. Notwithstanding the positive performance of the payment system, the circulation of money, i.e. currency outside banks as a means of payment, still played an important role in community transactions. This is reflected in the high growth of currency in circulation during the fourth quarter of 2012 along with the solid development of economic activity. 